\title{
Ions and the Action of Digitalis*
}

\author{
M. WEATHERALL \\ From the Department of Pharmacology, the London Hospital Medical College, London E.1
}

Digitalis acts mainly on the heart. It affects excitability, conduction of impulses, and force of contraction. The physiology of all these processes has been elucidated greatly in the past 20 years, particularly by Hodgkin and Huxley and their collaborators. Techniques of inserting micro-electrodes into nerve and muscle cells have made possible both the recording of transmembrane potentials in resting and excited cell membranes, and the control of these potentials in order to analyse them more accurately.

Since the currents that flow across the membrane, both at rest and during activity, are carried by ions, knowledge of membrane currents gives considerable information about the ionic movements through the membrane. Use of radioactive isotopes has provided another method for determining the magnitude of the ionic movements. The electrical method is much better able to follow rapid events, such as occur in a single nerve impulse or a single cardiac cycle, but it is unspecific about the ions concerned. Isotopes, on the other hand, allow unequivocal identification of the part played by a particular ion but they do not lend themselves to the study of events occurring in tissues in less than a minute or so. Both the techniques themselves and the knowledge they have afforded have been of great value in understanding how drugs act, not least for cardiac glycosides. The connexion between digitalis and several cations has been well known for half a century (Clark, 1912), and it is now possible at least to outline an account of the actions of cardiac glycosides in terms of their basic influence on ionic movements. These basic influences have recently been reviewed by Glynn (1964), who has contributed much to their study.

\footnotetext{
Received July 5, 1965.

$\star$ The Fourth Haile Selassie Lecture, delivered at the Royal Society of Medicine, London, on June 18, 1965, under the auspices of the National Heart Hospital.
}

The clinical aspects of digitalis have also recently been reviewed in McMichael's Withering lectures (1963). The principal purpose of this further discussion of the subject is to bring the two aspects closer together, and to pick out the growing points of knowledge where further advances can best be made.

\section{IONS AND EXCITABILITY OF THE HEART}

Cardiac muscle cells, like other kinds of muscle, and like nerve, contain a higher concentration of potassium and a lower concentration of sodium and of chloride than the surrounding fluid. The cell membranes are more or less permeable to all these ions, and a continuous exchange can be shown, both in vivo and in vitro, in beating or in quiescent hearts, by means of radioactive tracers. The interior of the cell membranes is negative relative to the exterior, except for a brief period during each action potential. Consequently, at rest, the electrical forces attract cations into the cells, and repel anions, and act in the opposite direction to the concentration gradients of potassium and of chloride. The electromotive force associated with a given difference of concentration of a univalent ion, for example, potassium, across a permeable membrane can be calculated from the Nernst equation,

$$
E=\frac{R T}{F} \log _{e} \frac{\left[K_{0}\right]}{\left[K_{1}\right]},
$$

and the differences are not large between observed membrane potentials and those calculated from internal and various external potassium concentrations (Vaughan Williams, 1959). Although differences are not entirely negligible, as a first approximation the distribution of potassium ions can be regarded as a resultant of an electrical gradient drawing the ions inward and a concentration gradient acting in the opposite direction. 
The distribution of sodium is less simple, because both the concentration gradient and the electrical gradient act in the same direction, moving sodium ions into the cells, but nevertheless the intracellular concentration of sodium is substantially lower than that of the surrounding medium. It follows that removal of sodium from cells involves performance of work, and therefore expenditure of metabolic energy. Correspondingly, it is observed that reduction of metabolic activity, by cooling or by anoxia or by poisoning, is associated with accumulation of sodium in cells, and restoration of activity is accompanied by recovery of normal ionic gradients. The mechanism of sodium extrusion is unknown. It has conveniently been described as the "sodium pump" (Dean, 1941), but it is still far from clear whether sodium ions are extruded by themselves, or in conjunction with an anion, or in exchange for a different cation, such as potassium. Either of the last two processes would be electrically neutral, whereas the first would contribute to the negative potential inside the cells, and thereby secondarily affect the transport of other ions. Cardiac glycosides have a striking action on the sodium pump, but even if they are regarded as selective blocking agents, their use has so far not helped very much in understanding the mechanism of the sodium pump.

An additional technical difficulty arises in studying the distribution and movements of sodium in tissues. Any piece of heart muscle is composed of cells held together by connective tissue with an appreciable amount of extracellular space. The space is filled with fluid, similar in composition to a dialysate of plasma or (in experiments on isolated hearts) to the medium in which the tissue is suspended or perfused. Such extracellular fluid is full of sodium. If it is replaced by a sodium-free solution, the cell membranes are affected and probably become abnormally leaky, so that the cells lose sodium. If the extracellular fluid is included in a portion of heart when the total tissue sodium is estimated, due allowance for extracellular sodium must be made by estimating or assuming the volume and sodium concentration of extracellular fluid. It is more usual to estimate the extracellular volume by a suitable labelling molecule, such as inulin, which is expected to diffuse freely outside cells and not to enter cells at all. On the assumption that the extracellular fluid has the same composition as the medium in which the tissue is maintained, the total quantity of extracellular sodium can be calculated and the intracellular amount obtained by difference. Unfortunately, no two marker substances give the same estimate of the extracellular volume (Barclay, Hamley, and Houghton, 1959; Goodford and Hermansen, 1961; Rayner, 1962), though most markers distribute in a larger volume than histological examination suggests (Johnson and Simonds, 1962). Possibly the extracellular space extends ultimately to channels small enough to prevent diffusion of large molecules. Alternatively, large molecules naturally present, such as hyaluronic acid, may obstruct the entry of other large molecules, as has been shown to occur in vitro (Ogston and Phelps, 1961). Moreover, the extracellular space is not constant in a given tissue, but diminishes in circumstances in which the cells of the tissue are likely to swell (Carslake and Weatherall, 1962). For all these reasons, estimates of intracellular sodium concentration, which is the physiologically important measurement, are at best questionable and at worst entirely misleading. There is no doubt about the direction of the sodium concentration gradient, but its magnitude in heart muscle is uncertain.

The third principal univalent ion, chloride, behaves more like potassium than sodium in that differences in concentration inside and outside the cells are in the direction expected from the resting membrane potential. If the distribution both of chloride and of potassium were purely a passive process and reached an equilibrium in which the electrical potential balanced the chemical concentration gradient, the ratio of concentration inside and outside should correspond for both ions, because the Nernst equation is applicable in either case. However, the exact intracellular chloride concentration is as uncertain as the intracellular sodium concentration, and for the same reason, that much chloride is extracellular, and the amount so accounted for is uncertain. It remains to be discovered whether the chloride ratio is equal to the potassium ratio (as would be expected if both ions were passively distributed) or considerably smaller as some estimations suggest (Carslake and Weatherall, 1962).

\section{Excitation}

The normal concentrations of ions represent a steady state in which active transport processes counteract the natural leakiness of the cell membranes. Excitation of the heart involves an increase in leakiness, initially to the ion which is furthest from an equilibrium distribution, i.e. sodium, and later at least to potassium. As in nerve, the process of depolarization results from an increase in permeability to sodium. The occurrence of depolarization augments the increase in permeability, so that positive feedback occurs and produces the extremely rapid upshoot of the action potential, familiar from all intracellular recordings. Re- 
covery involves passage of current in the opposite direction, most of which current is probably carried by potassium ions. The events are easy to recognize electrically, and partly by analogy with nerve and partly by experiments in which ionic concentrations are altered artificially, the ions involved can be identified with some certainty. It ought to be possible, as in nerve (Keynes and Lewis, 1951; Hodgkin and Keynes, 1957), to confirm both identity and quantity by measurements with radioactive tracers.

In practice, heart muscle has been less amenable than nerve to these techniques. To make good measurements of ionic movements with isotopes, it is desirable to have as simple a system as possible, preferably consisting of single muscle fibres (Hodgkin and Horowicz, 1959). Mammalian heart muscle, even an atrium from small or young animals, is by these standards thick tissue, at least 10 or 20 cells across, and its extracellular space presents a complex diffusion zone between most of the cell walls and the exterior. However, isolated atria of guinea-pigs or young rabbits survive and beat actively and maintain normal ionic concentrations for many hours in a suitable medium, and, despite their limitations, their exchange of sodium and potassium has been studied in several laboratories. Atria have an additional convenience. An isolated left atrium becomes quiescent within a minute or two of setting up the preparation, and remains so unless it is stimulated electrically or treated with catechol amines, or if the concentration of potassium in the medium is abnormally low. The comparison between the inactive and the stimulated left atrium has been useful in numerous ways, and has shown, for instance, an accelerated turnover of potassium in relation to beating (Fig. 1). With the thinner tissues of the frog sinus venosus, Harris and Hutter (1956) have shown a much bigger increase in potassium efflux during activity. In general, potassium turnover has been relatively easy to study, perhaps because so little potassium is extracellular. Exchange, at least in mammalian tissue, does not follow a single exponential process, either in quiescent or beating tissues, and fractionation of the tissue has shown that the mitochondria actively exchange potassium with their surroundings (Ulrich, 1960; Weatherall, 1962b) and so contribute to the heterogeneity which can be deduced from observed tracer movements (Persoff, 1960; Weatherall, 1962a). Sodium movements have been much more elusive. The efflux of ${ }^{24} \mathrm{Na}$ from an atrium loaded with tracer follows, like that of ${ }^{42} \mathrm{~K}$, a course which consists of more than one exponential process, but unlike that of ${ }^{42} \mathrm{~K}$ cannot be satisfactorily resolved into linear components (Carslake and Weatherall, $2 \mathrm{~K}$
1962). Increased efflux during beating has been described (Sekul and Holland, 1960; Haas, Glitsch, and Trautwein, 1963; Sjöstrand, 1964), though the increase shown is small compared with what electrophysiological observations suggest (Noble, 1962). It seems likely that diffusion delays in extracellular fluids, perhaps related to those which make measurement of extracellular volume so difficult, obscure many of the events occurring at cell membranes, and limit the usefulness of isotopes to the study of changes occurring over longer periods of time.

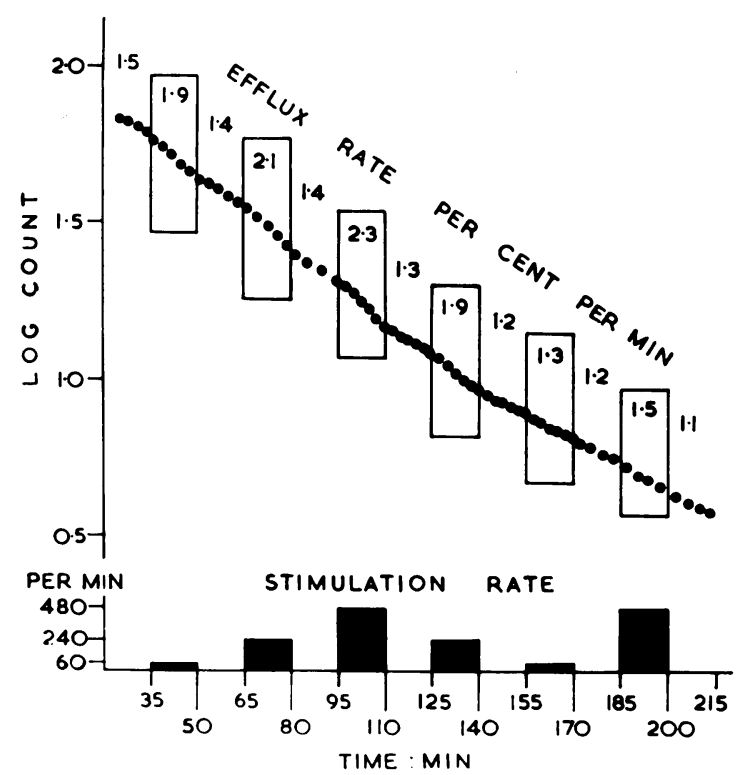

Fig. 1.-Efflux of $42 \mathrm{~K}$ from rabbit left atrium alternately quiescent and stimulated at different rates for periods of 15 minutes (Rayner and Weatherall, 1959).

\section{INFLUENCE OF CARDIAC Glycosides}

The effects of drugs have more suitable time relations for study by means of tracers, and effects of cardiac glycosides on potassium fluxes have been clearly shown by many authors. As Fig. 2 shows, entry of potassium to beating atria is arrested within a minute or so by high concentrations of ouabain. Similar effects can be shown with less ouabain, but in heart muscle in vitro it is difficult to detect any change with concentrations below about $10^{-6} \mathrm{M}$. Effective concentrations are therefore considerably higher than those likely to occur during the therapeutic use of the drug (probably about $1-5 \times 10^{-8} \mathrm{M}$.). However, the duration of exposure in such experiments is generally much shorter and this factor is of considerable importance and is 
discussed later. The effect on potassium influx is not specific to heart muscle, but only erythrocytes appear to be substantially more sensitive (Schatzmann, 1953). Impaired uptake of potassium has been detected in red cells within an hour or so of immersion in as little as $10^{-8} \mathrm{M}$ ouabain or other cardiac glycosides (Glynn, 1957). Why red cells should be particularly sensitive or what physiological significance should be attached to their sensitivity is still unknown.

Efflux of sodium is also arrested by cardiac glycosides. The effect is less easy to show, because of the large amounts of extracellular sodium, but it has been convincingly demonstrated in red cells (Glynn, 1957), skeletal muscle (Matchett and Johnson, 1954), kidney tubules (Farber et al., 1951; Orloff and Burg, 1958), gastric mucosa (Cooperstein, 1959), nerve (Caldwell and Keynes, 1959), and smooth muscle (Schatzmann and Ackermann, 1961).

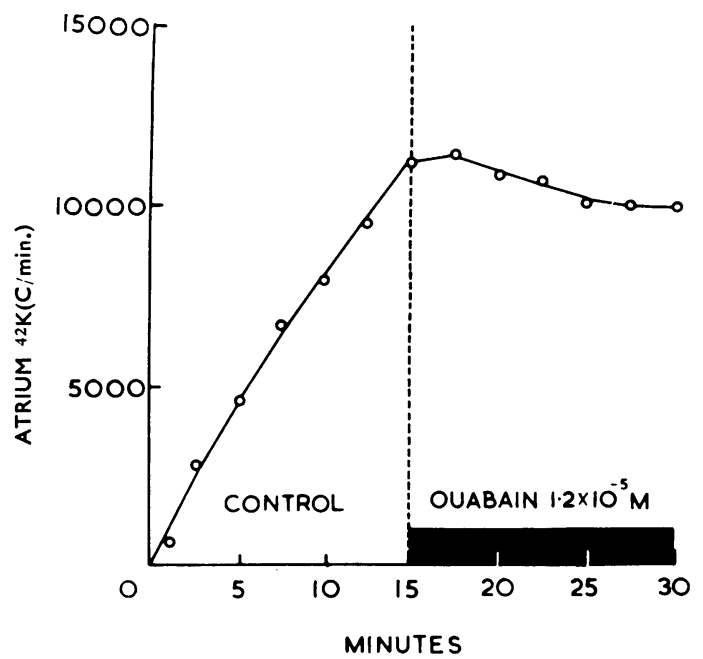

FIG. 2.-Effect of ouabain $\left(1.2 \times 10^{-5} \mathrm{M}\right)$ on the uptake of potassium-42 in the right atrium of the rabbit (Weatherall, 1962c).

One can regard the inhibition of the sodium pump as primary and the impairment of potassium entry as a consequence, or treat both events as the outcome of blocking a sodium-for-potassium exchange system. In any case, active transport is arrested, but (apart from red cells) only by "toxic" and not "therapeutic" concentrations of cardiac glycosides (Rayner and Weatherall, 1957; Klaus, Kuschinsky, and Lüllmann, 1962). Nevertheless, the effect is closely correlated with cardiac activity.
Three separate studies (Kahn and Acheson, 1955; Glynn, 1957; Strickler and Kessler, 1961) have shown that diminution of cardiac potency goes with diminution of effect on ionic transport. The change in active transport is not associated with a change of equal magnitude in passive movements. Whether any change at all occurs in either potassium efflux or in sodium influx has been debated, but whatever alteration occurs is small compared with the effect on active movements. Consequently, the cells gain sodium and lose potassium, and in this situation the membrane potential becomes less negative and nearer to the critical level for spontaneous depolarization, and probably consequentially their excitability increases. A loss of about 10 per cent of intracellular potassium has been associated with cessation of spontaneous activity (Rayner and Weatherall, 1957) attributable to persistent depolarization. The association of arrhythmias of digitalis poisoning with smaller losses of potassium was suggested long before turnover of ${ }^{42} \mathrm{~K}$ had been studied (Calhoun and Harrison, 1931; Wood and Moe, 1938; Wedd, 1939). An increased concentration of potassium in the surrounding medium diminishes, and a decreased concentration increases, the magnitude of the loss of potassium. Correspondingly, the toxicity of digitalis is augmented by a reduction in plasma or medium potassium, as has long been known experimentally (Clark, 1912; Baker, 1947) and has become of great practical importance since the use of thiazide diuretics became widespread. Inhibition of active transport of univalent cations accounts for the toxic actions of digitalis, but an additional factor appears to be involved in the lower threshold activity on the force of cardiac contraction.

\section{ExCITATION-CONTRACTION COUPLING}

When a muscle cell membrane is depolarized, the event is normally followed by contraction of the myofibrils within the cell. It is becoming increasingly clear that the two events are linked by the movement of calcium ions. That an ion should be responsible is likely, because a charged, chemically reactive, entity provides a simple mediator released by depolarization and able rapidly to activate the chemical events of contraction. That calcium is responsible was suggested by observations of Heilbrunn and Wiercinski (1947), who showed that calcium salts initiated contraction of myofibrils when the salts were injected intracellularly, and that other physiologically common ions were inactive or active only in concentrations higher by an order of magnitude. Doubts have been raised whether 
any substance could diffuse rapidly enough from the cell membrane to the myofibrils to be effective in the very short delay between excitation and contraction (Hill, 1948). These doubts have been met by demonstration that the endoplasmic reticulum behaves as an inward extension of the cell membrane and permits the electrochemical events of the depolarization to be brought much closer to the critical points at which contraction is initiated (Huxley and Taylor, 1958; Simpson and Oertelis, 1962; Nelson and Benson, 1963). Isolated endoplasmic reticulum has considerable capacity to concentrate calcium (Hasselbach and Makinose, 1961; Ebashi and Lipmann, 1962), and recently Winegrad (1964) has reported that autoradiographs of frog skeletal muscle containing ${ }^{45} \mathrm{Ca}$ show concentration of calcium around the $Z$ lines if the muscle is depolarized and relaxed during fixation, and concentration predominantly in the $\mathrm{A}$ band region in muscles which have developed tension while they were fixed.

In heart muscle also, calcium is probably the mediator between excitation and contraction. As Ringer (1883) observed, calcium is essential for regular cardiac contractions. The force with which an isolated heart beats depends on the concentration of calcium in the medium which surrounds it. The effectiveness of calcium applied externally is particularly apparent when the cells are depolarized. For instance, the force of a contraction can be increased if a calcium salt is injected into the coronary artery at the moment of depolarization (Weidmann, 1959), and the tone of a persistently depolarized heart depends on the surrounding concentration of calcium. The supposed mechanism of excitationcontraction coupling does not necessarily involve an increased turnover of calcium by the whole tissue. However, accelerated turnover of calcium during beating is well known in the heart (Niedergerke and Harris, 1957; Briggs and Holland, 1960; Thomas, 1960; Lüllmann and Holland, 1962; Winegrad and Shanes, 1962; Niedergerke, 1963), and prima facie this calcium is likely to be involved in the process of activation of the muscle. Analysis of what happens to the extra calcium which is taken up, and even simple measurement of the amount involved, presents difficulties, because calcium in the tissues and extracellular space is in several fractions. In such circumstances, studies with a single tracer give limited and sometimes misleading information, and progress depends on isolating the various fractions concerned (cf. Weatherall, 1962a, b). Identification of the fractions of calcium in the heart has not yet reached the position of an exact description of the behaviour of this ion in the quiescent or beating tissue.

\section{Cardiac Glycosides and Contraction}

Until the normal movements of calcium are known, any account of the influence of cardiac glycosides on them must also be incomplete. However, enough evidence has accumulated to make coherent hypotheses which are open to experimental proof or disproof. Radioactive calcium accumulates to a greater extent in beating mammalian atrial tissue and in frog hearts when they are exposed to ouabain or digitoxigenin (Holland and Sekul, 1959; Thomas, 1960; Klaus and Kuschinsky, 1962; Lüllmann and Holland, 1962), and with toxic concentrations a net gain of calcium has been reported (Klaus et al., 1962; Lee et al., 1961; Lüllmann and Holland, 1962). The accumulation could result from an increased uptake of calcium or a diminished extrusion, or both, and any of these effects might be due to a primary action on transport mechanisms or secondary to an increased binding capacity of a calcium-holding structure in the tissue. It seems reasonably certain that some of the accumulated calcium is present at a site which regulates the magnitude of contractions of the heart. Since this calcium is normally released by depolarization, much information can be obtained by modifying the ionic environment of the heart so that a sustained depolarization occurs. This technique was suggested by the elegant experiments of Evans, Schild, and Thesleff (1958) on preparations of smooth muscle, and has recently been applied to cardiac muscle (Walker and Weatherall, 1964). When rabbit atria are depolarized by excess potassium, they normally remain relaxed unless additional calcium is added (Fig. 3). If the atria have been beating in the presence of ouabain, they contract immediately on depolarization, without the addition of further calcium, slowly compared with a normal contraction, but more rapidly than can be achieved by adding calcium outside the tissue. This contraction, or contracture, behaves very like a contracture induced by calcium. It is inhibited by the chelating agent ethylenediaminetetra-acetate; it is reversible on washing out; recovery does not occur in the absence of oxygen; and the rate of recovery from either kind of contraction lies within the same rather narrow limits. The simplest explanation of the observations is that the spontaneous contracture on depolarization of the ouabain-treated atrium is due to an excess of calcium accumulated at the cell membrane under the influence of ouabain.

The liability to contracture, like the force of the ordinarily beating isolated heart, is much affected by the previous activity of the heart. When a similar experiment is performed on a left atrium which contains no pacemaker and does not beat 
spontaneously, no contracture occurs on depolarization by excess potassium, and even the addition of extra calcium has little effect (Fig. 3a). Nor, in this circumstance, does previous exposure to a cardiac glycoside promote contracture, either spontaneously or on adding calcium ions (Fig. 3c), unless much higher concentrations of glycoside are used. The (a)
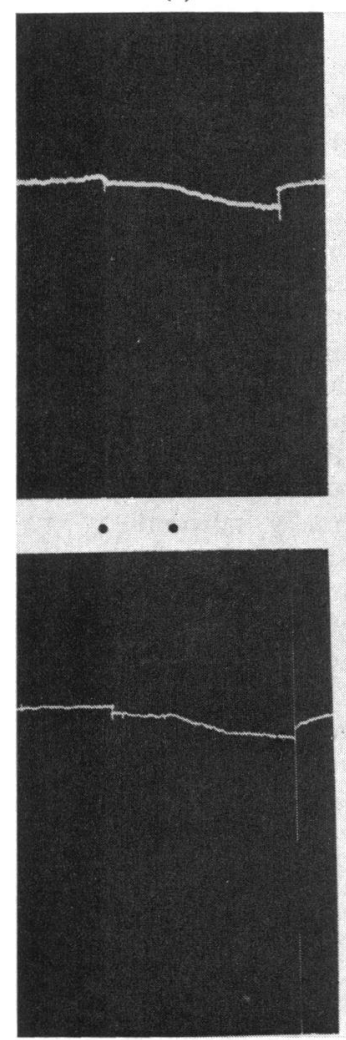

(c) (b)

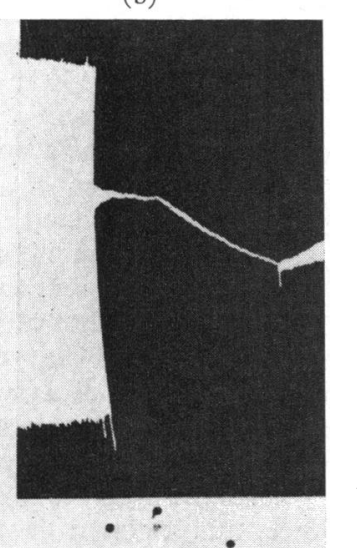

(d)

Frg. 3.-Effect of beating and of ouabain on contracture of left atrium. (a) Atrium quiescent for 10 minutes in normal medium; at first dot transferred to higher potassium medium; at second dot calcium chloride added. (b) As (a) but atrium stimulated at 2.6 per second in normal medium. (c) and (d) As (a) and (b) for $2 \times 10^{-6} \mathrm{M}$ ouabain. At the end of record (d), edetic acid was added and the contracture arrested (Walker and Weatherall, 1964).

relation between frequency and force of contraction has fascinated and puzzled physiologists for nearly a century since Bowditch (1871) described the "staircase" phenomenon, but it is now widely recognized that accumulation of calcium at each contraction and its gradual leaking away during inactivity is fundamental to the process (Koch-Weser and Blinks, 1963, for review). In the same way, the inotropic

effect of cardiac glycosides depends on activity of the heart (Clark, 1912; Konschegg, 1913), and it seems likely that prevention of the slow leaking away of calcium accumulated during activity at the crucial site is fundamental to the action of the glycosides.

At a given concentration of cardiac glycoside, the total number of beats before applying the depolarizing solution appears largely to determine the size of the response, and sufficiently long exposure at a sufficiently rapid rate allows contractures to appear after exposure to considerably lower concentrations of glycoside than have been shown to affect the sodium pump (Sekul and Holland, 1960). An action after 2 hours at one part in 10 million is in the same range as the therapeutic activity of digitalis. As the effect is augmented by beating, it develops sooner if there is tachycardia. The greater sensitivity of the failing heart is perhaps largely due to its greater rate of beating. Similarly, in skeletal muscle, force of contraction is augmented by cardiac glycosides only after a period of activity in the muscle (Cattell, 1938). It is likely that the apparently specific action of digitalis on the heart results simply from the fact that the heart is the only continuously active muscle in the body, and so is affected while muscles without the same relentless calcium turnover are not vulnerable to inhibition of the calcium ejecting mechanism.

The final mechanism by which cardiac glycosides achieve accumulation of calcium in a beating heart is still open to discussion. Calcium and sodium compete for entry to the heart (Lüttgau and Niedergerke, 1958), and indeed effects like those of cardiac glycosides can be produced on isolated hearts simply by reducing the external concentration of sodium (Daly and Clark, 1921; Wilbrandt and Koller, 1948; Walker and Weatherall, 1964). Like sodium, calcium leaves cells against an electrochemical potential gradient. Do both ions leave by a common active transport mechanism? The nature of the sodium transport mechanism is still a mystery. It appears to be associated with a particular adenosine triphosphatase (Dunham and Glynn, 1961; Whittam, 1962) which is sensitive to cardiac glycosides, and to the internal concentrations of sodium and calcium and the external concentration of potassium. Autoradiographic evidence (Fozzard and Smith, 1965) suggests that this enzyme is associated with the sarcoplasmic reticulum and that most of the digoxin taken up by heart muscle is perhaps located in the same region (Conrad and Baxter, 1964). Strong arguments have been put forward (Repke, 1965) for associating the inotropic action of cardiac glycosides with their effect on the "transport" adenosine triphosphatase. It remains 
to be shown whether this enzyme is concerned also with removal of calcium from the trigger site. If the consequences of inhibiting calcium extrusion developed more rapidly than those of accumulating sodium, greater sensitivity of the contractile system than of the excitatory mechanism to digitalis would be explained.

\section{CoNClusions}

These observations raise some interesting practical questions. Is it possible to increase the therapeutic effects of digitalis and to diminish the toxic effects? The two mechanisms appear to be separate and yet to have identical molecular requirements. Perhaps more could be done by altering the conditions in which the drug acts. So far the accidental enhancement of toxicity produced by thiazide diuretics or occasionally by administration of calcium salts has been more prominent than attempts to minimize arrhythmias by giving extra potassium salts. It is also interesting to ask why the failing heart benefits from the action of digitalis. The failure of calcium movement may be fundamental in the pathogenesis of failure: or the action of digitalis may be purely palliative, boosting one part of the mechanism so that defects of another part are temporarily covered. There is still much to be discovered, but the general mode of action of cardiac glycosides is clearer than it has ever previously been.

The author is much indebted to a number of his colleagues who took part in the experiments reviewed above, particularly to Mrs. Mary Perrins (formerly Miss Carslake), Miss B. B. Rayner, Dr. A. Stafford, and Mr. J. M. G. Walker, and to Dr. P. J. Goodford for valuable discussions. He is also indebted to the Editors of the fournal of Physiology for permission to reproduce Fig. 1, to the Ciba Foundation and Messrs. J. A. Churchill for permission to reproduce Fig. 2, and to the Editors of the British fournal of Pharmacology for permission to reproduce Fig. 3.

\section{REFERENCES}

Baker, J. B. E. (1947). The influence of calcium and potassium ions on the toxicity of ouabain. Brit. $\mathcal{F}$. Pharmacol., 2, 259.

Barclay, J. A., Hamley, E. J., and Houghton, H. (1959). The inulin, sucrose, chloride and sodium space of the isolated perfused rat heart. F. Physiol. (Lond.), 149, 15p.

Bowditch, H. P. (1871). [Quoted by Koch-Weser and Blinks (1963).] Ber. math. -phys. Sachs. Ges. Wiss. Leipzig, 23, 652.

Briggs, A. H., and Holland, W. C. (1960). Effects of epinephrine and $\mathrm{Ca}$ on contractile strength and $\mathrm{Ca}^{45}$ exchange in rabbit atria. Amer. F. Physiol., 199, 609.

Caldwell, P. C., and Keynes, R. D. (1959). The effect of ouabain on the efflux of sodium from a squid giant axon. F. Physiol. (Lond.), 148, 8P.

Calhoun, J. A., and Harrison, T. R. (1931). Studies in congestive heart failure. IX. The effect of digitalis on the potassium content of the cardiac muscle of dogs. F. clin. Invest., 10, 139.
Carslake, M. C., and Weatherall, M. (1962). Changes in the sodium, potassium and chloride of rabbit auricles treated with ouabain. F. Physiol. (Lond.), 163, 347.

Cattell, McK. (1938). The influence of ouabain on the contraction of striated muscle. F. Pharmacol. exp. Ther., $62,459$.

Clark, A. J. (1912). The influence of ions upon the action of digitalis. Proc. roy. Soc. Med., 5, Therap. Pharmacol. Sect., p. 181.

Conrad, L. L., and Baxter, D. J. (1964). Intracellular distribution of digoxin- $\mathrm{H}^{3}$ in the hearts of rats and dogs demonstrated by autoradiography and its relationship to changes in myocardial contractile force. F. Pharmacol. exp. Ther., 145, 210.

Cooperstein, I. L. (1959). The inhibitory effect of strophanthidin on secretion by the isolated gastric mucosa. $\mathcal{F}$. gen. Physiol., 42, 1233.

Daly, I. de B., and Clark, A. J. (1921). The action of ions upon the frog's heart. f. Physiol. (Lond.), 54, 367.

Dean, R. B. (1941). Theories of electrolyte equilibrium in muscle. Biol. Symp., 3, 331.

Dunham, E. T., and Glynn, I. M. (1961). Adenosinetriphosphatase activity and the active movements of alkali metal ions. F. Physiol. (Lond.), 156, 274.

Ebashi, S., and Lipmann, F. (1962). Adenosine triphosphatelinked concentration of calcium ions in a particulate fraction of rabbit muscle. $\mathcal{~ f . ~ C e l l ~ B i o l . , ~ 1 4 , ~} 389$.

Evans, D. H. L., Schild, H. O., and Thesleff, S. (1958). Effects of drugs on depolarized plain muscle. f. Physiol. (Lond.), 143, 474.

Farber, S. J., Alexander, J. D., Pellegrino, E. D., and Earle, D. P. (1951). The effect of intravenously administered digoxin on water and electrolyte excretion and on renal functions. Circulation, 4, 378.

Fozzard, H. A., and Smith, J. R. (1965). Observations on the localization of tritiated digoxin in myocardial cells by autoradiography and ultramicroscopy. Amer. Heart f., 69, 245.

Glynn, I. M. (1957). The action of cardiac glycosides on sodium and potassium movements in human red cells. f. Physiol. (Lond.), 136, 148.

- (1964). The action of cardiac glycosides on ion movements. Pharmacol. Rev., 16, 381.

Goodford, P. J., and Hermansen, K. (1961). Sodium and potassium movements in the unstriated muscle of the guinea-pig tænia coli. F. Physiol. (Lond.), 158, 426.

Haas, H. G., Glitsch, H. G., and Trautwein, W. (1963). Natrium-Fluxe am Vorhof des Froschherzens. Pflügers Arch. ges. Physiol., 277, 36.

Harris, E. J., and Hutter, O. F. (1956). The action of acetylcholine on the movements of potassium ions in the sinus venosus of the heart. F. Physiol. (Lond.), 133, 58P.

Hasselbach, W., and Makinose, M. (1961). Die Calciumpumpe der "Erschlaffungsgrana" des Muskels und ihre Abhängigkeit von der ATP-Spaltung. Biochem. Z., 333, 518.

Heilbrunn, L. V., and Wiercinski, F. J. (1947). The action of various cations on muscle protoplasm. $\mathcal{~ f . ~ c e l l . ~ c o m p . ~}$ Physiol., 29, 15.

Hill, A. V. (1948). On the time required for diffusion and its relation to processes in muscle. Proc. roy. Soc. $B$, $135,446$.

Hodgkin, A. L., and Horowicz, P. (1959). Movements of $\mathrm{Na}$ and $\mathrm{K}$ in single muscle fibres. $\mathcal{F}$. Physiol. (Lond.), $145,405$.

$\longrightarrow$, and Keynes, R. D. (1957). Movements of labelled calcium in squid giant axons. $\mathcal{F}$. Physiol. (Lond.), 138, 253.

Holland, W. C., and Sekul, A. A. (1959). Effect of ouabain on $\mathrm{Ca}^{45}$ and $\mathrm{Cl}^{36}$ exchange in isolated rabbit atria. Amer. f. Physiol., 197, 757. 
Huxley, A. F., and Taylor, R. E. (1958). Local activation of striated muscle tibres. F. Physiol. (Lond.), 144, 426.

Johnson, J. A., and Simonds, M. A. (1962). Chemical and histological space determinations in rabbit heart. Amer. 7. Physiol., 202, 589.

Kahn, J. B., Jr., and Acheson, G. H. (1955). Effects of cardiac glycosides and other lactones, and of certain other compounds, on cation transfer in human erythrocytes. F. Pharmacol. exp. Ther., 115, 305.

Keynes, R. D., and Lewis, P. R. (1951). The resting exchange of radioactive potassium in crab nerve. $\mathcal{F}$. Physiol. (Lond.), 113, 73.

Klaus, W., and Kuschinsky, G. (1962). Über die Wirkung von Digitoxigenin auf den cellulären Calcium-Umsatz im Herzmiskelgewebe. Naunyn-Schmiedeberg's Arch. exp. Path. Pharmak., 244, 237.

,-- , and Lüllmann, H. (1962). Über den Zusammenhang zuischen positiv inotroper Wirkung von Digitoxigenin, Kaliumflux und intracellulären Ionenkonzentrationen im Herzmuskel. Naunyn-Schmiedeberg's Arch. exp. Path. Pharmak., 242, 480.

Koch-Weser, J., and Blinks, J. R. (1963). The influence of the interval between beats on myocardial contractility. Pharmacol. Rev., 15, 601.

Konschegg, A. von (1913). Über Beziehungen zqischen Herzmittel-und physiologischer Kationenwirkung. Naunyn-Schmiedeberg's Arch. exp. Path. Pharmak., 71, 251.

Lee, K. S., Yu, D. H., Lee, D. I., and Burstein, R. (1961). The influence of potassium and calcium on the effect of ouabain on cat papillary muscles. f. Pharmacol. exp. Ther., $132,139$.

Lüllmann, H., and Holland, W. (1962). Influence of ouabain on an exchangeable calcium fraction, contractile force, and resting tension of guinea-pig atria. f. Pharmacol. exp. Ther., 137, 186.

Lüttgau, H. C., and Niedergerke, R. (1958). The antagonism between $\mathrm{Ca}$ and $\mathrm{Na}$ ions on the frog's heart. F. Physiol. (Lond.), 143, 486.

Matchett, P. A., and Johnson, J. A. (1954). Inhibition of sodium and potassium transport in frog sartorii in the presence of ouabain. Fed. Proc., 13, 384.

McMichael, J. (1963). The heart and digitalis. Brit. med. f., 2, 73.

Nelson, D. A., and Benson, E. S. (1963). On the structural continuities of the transverse tubular system of rabbit and human myocardial cells. F. Cell Biol., 16, 297.

Niedergerke, R. (1963). Movements of $\mathrm{Ca}$ in frog heart ventricles at rest and during contractures. $\mathcal{F}$. Physiol. (Lond.), 167, 515.

- , and Harris, E. J. (1957). Accumulation of calcium (or strontium) under conditions of increasing contractility. Nature (Lond.), 179, 1068.

Noble, D. (1962). A modification of the Hodgkin-Huxley equations applicable to Purkinje fibre action and pacemaker potentials. F. Physiol. (Lond.), 160, 317.

Ogston, A. G., and Phelps, C. F. (1961). The partition of solutes between buffer solutions and solutions containing hyaluronic acid. Biochem. F., 78, 827.

Orloff, J., and Burg, M. (1958). A direct renal tubule effect of strophanthidin on electrolyte excretion in the chicken. Amer. F. Med., 25, 129.

Persoff, D. A. (1960). A comparison of methods for measuring efflux of labelled potassium from contracting rabbit atria. F. Physiol. (Lond.), 152, 354.

Rayner, B. (1962). Personal communication to Carslake and Weatherall.

- , and Weatherall, M. (1957). Digoxin, ouabain and potassium movements in rabbit auricles. Brit. $\mathcal{F}$. Pharmacol., 12, 371. and - (1959). Acetycholine and potassium movements in rabbit auricles. F. Physiol. (Lond.), 146, 392.

Repke, K. (1965). Effect of digitalis on membrane adenosine triphosphatase of cardiac muscle. In Proc 2nd. Internat. Pharmacol. Meeting. Prague, 1963, Vol 4: Drugs and Enzymes, p. 65-87. Pergamon Press, Oxford.

Ringer, S. (1883). A further contribution regarding the influence of the different constitutents of the blood on the contraction of the heart. F. Physiol. (Lond.), 4, 29.

Schatzmann, H. J. (1953). Herzglykoside als Hemmstoffe für den aktiven Kalium-und Natriumtransport durch die Erythrocytenmembran. Helv. physiol. pharmacol. Acta, 11, 346.

- - , and Ackermann, H. (1961). Die Strophanthinwirkung am Darmmuskel und ihre Beziehung zum Kationengehalt des Mediums. Helv. physiol. pharmacol. Acta, 19, 196.

Sekul, A. A., and Holland, W. C. (1960). Effects of ouabain on $\mathrm{Ca}^{45}$ entry in quiescent and electrically driven rabbit atria. Amer. F. Physiol., 199, 457.

Simpson, F. O., and Oertelis, S. J. (1962). The fine structure of sheep myocardial cells: sarcolemmal invaginations and the transverse tubular system. F. cell Biol., 12, 91 .

Sjöstrand, U. (1964). Analysis of ionic tracer movements durıng single heart cycles. Acta physiol. scand., 61, Suppl. 227.

Strickler, J. C., and Kessler, R. H. (1961). Direct renal action of some digitalis steroids. $\mathcal{F}$. clin. Invest., 40, 311 .

Thomas, L. J. (1960). Increase of labeled calcium uptake in heart muscle during potassium lack contracture. $\mathcal{F}$. gen. Physiol., 43, 1193.

Ulrich, F. (1960). Active transport of potassium by heart mitochondria. Amer. F. Physiol., 198, 847.

Vaughan Williams, E. M. (1959). The effect of changes in extracellular potassium concentration on the intracellular potentials of isolated rabbit atria. f. Physiol. (Lond.), 146, 411.

Walker, J. M. G., and Weatherall, M. (1964). Calcium in relation to the actions of ouabain and adrenaline on the heart. Brit. F. Pharmacol., 23, 66.

Weatherall, M. (1962a). Quantitative analysis of movements of potassium in rabbit auricles. Proc. roy. Soc. $B, 156$, 57.

- (1962b). Location of fractions of potassium in rabbit auricles. Proc. roy. Soc. $B, \mathbf{1 5 6}, 83$.

- (1962c). Action of cardiac glycosides on ionic movements. In Ciba Foundation Symposium on Enzymes and Drug Action, pp. 115-126. Churchill, London.

Wedd, A. M. (1939). The influence of digoxin on the potassium content of heart muscle. $\mathcal{F}$. Pharmacol. exp. Ther., 65, 268.

Weidmann, S. (1959). Effect of increasing the calcium concentration during a single heart-beat. Experientia (Basel), 15, 128.

Whittam, R. (1962). The asymmetrical stimulation of a membrane adenosine triphosphatase in relation to active cation transport. Biochem. F., 84, 110.

Wilbrandt, W., and Koller, H. (1948). Die CalciumWirkung am Froschherzen als Funktion des Ionengleichgewichts zwischen Zellmembran und Umgebung. Helv. physiol. pharmacol. Acta, 6, 208.

Winegrad, S. (1964). Calcium and the initiation of contraction. Circulat. Res., 15, Suppl. 2, p. 61.

- , and Shanes, A. M. (1962). Calcium flux and contractility in guinea pig atria. F. gen. Physiol., 45, 371 .

Wood, E. H., and Moe, G. K. (1938). Studies on the effect of the digitalis glucosides on potassium loss from the heart of the heart lung preparation. Amer. F. Physiol., $123,219$. 